\title{
Agriculture Role on Indian Economy
}

\section{Madhusudhan L*}

Department of Biotechnology, Joginpally B R Engineering College, JNTU, Telangana State, India

\section{Introduction}

Agriculture is the most important sector of Indian Economy. Indian agriculture sector accounts for 18 per cent of India's gross domestic product (GDP) and provides employment to $50 \%$ of the countries workforce. India is the world's largest producer of pulses, rice, wheat, spices and spice products. India has many areas to choose for business such as dairy, meat, poultry, fisheries and food grains etc. India has emerged as the second largest producer of fruits and vegetables in the world [1]. According to the data provided by Department of Economics and Statics (DES) the production of food grains for the year 2013-2014 is 264 million tons which is increased when compared to (2012-2013) 257million tons. This is a good symptom for the Indian economy from the agriculture sector. India remains among main three as far as production of different agricultural things like paddy, wheat, pulses, groundnut, rapeseeds, natural products, vegetables, sugarcane, tea, jute, cotton, tobacco leaves and so on. On the other hand, on advertising front, Indian agribusiness is as yet confronting the issues, for example, low level of business sector reconciliation and integration, availability of dependable and convenient information needed by farmers on different issues in farming [2].

\section{Agriculture in Indian Economy}

Indian is an agriculture based country, where more than $50 \%$ of population is depend on agriculture. This structures the main source of income. The commitment of agribusiness in the national income in India is all the more, subsequently, it is said that agriculture in India is a backbone for Indian Economy. The contribution of agriculture in the initial two decades towards the total national output is between $48 \%$ and $60 \%$. In the year 2001-2002, this contribution declined to just around 26\%. The aggregate Share of Agriculture and Allied Sectors, Including agribusiness, domesticated animals, and ranger service and fishery sub segments as far as rate of GDP is 13.9 percent during 201314 at 2004-05 prices. Agricultural exports constitute a fifth of the total exports of the country. In perspective of the overwhelming position of the Agricultural Sector, gathering and support of Agricultural Statistics expect incredible significance.

According to the fourth Advance Estimates of Production of food grains for 2013-14, aggregate food grain production is assessed to be 264.77 million tons (MT).

Export of spices from India are relied upon to reach US\$ 3 billion by $2016-17$, on the back of imaginative promoting strategies, inventive bundling, quality in quality and an in number appropriation system. The Indian flavors business is pegged at Rs 40,000 crore (US\$ 6.42 billion) every year, of which the marked portion represents $15 \%$ [3].

The National Food Security Mission (NFSM) was launched from Rabi, 2007-08. The fundamental targets of the National Food Security Mission (NFSM) is to expand production of rice, wheat, pulses and coarse cereals through region extension and efficiency upgrade in a supportable way in the recognized locale of the nation; restoring soil ripeness and profitability at the individual ranch level; and improving farm level economy (i.e. ranch benefits) to restore confidence amongst the farmers. The Mission met with a staggering achievement and accomplished the focused on extra generation of rice, wheat and heartbeats. The Mission is being kept amid Twelfth Five Year Plan with new focuses of extra generation of sustenance grains of 25 million tons including 10 million tons of rice, 8 million tons of wheat, 4 million tons of pulses and 3 million tons of coarse cereals by the end of twelfth five year plan [4].

Training is an important procedure of capacity building of people as to enhance the execution. Consequently, training needs appraisal is imperative to the training process. It serves to recognize present issues and future difficulties to be met through training and improvement. It is obliged to figure out the needs of individual trainee on which proficient skills ought to be assembled to do the relegated occupation in the associations [5].

The $6 \%$ of agricultural production is converted in to processed food, which is focused to achieve $20 \%$ in coming future. The business is work escalated and contributes around 50\% for industrial production. MultiNational Food Companies have assumed a part of making business sector draw and rivalry. Selection of inventive and experimental bundling strategies by food industry has empowered the assembling of sheltered and quality sustenance [6].

\section{Conclusion}

Most of the Indians are directly or indirectly depending on the agriculture. Some are directly attached with the farming and some other people are involved in doing business with these goods. India has the capacity to produce the food grains which can make vast difference in Indian Economy. To achieve targeted mark by the government it needs to provide support in case of land, bank loans and other machineries to the small farmers along with the big farmers with this we can expect some improvement in Indian economy.

\section{References}

1. Ministry of External Affairs (2015) India in Business. Investment and Technology Promotion Division, Govt. of India.

2. http://www.ccsniam.gov.in/research/KCG\%20Final\%20report.pdf

3. Indian Brand Equity Foundation (2015) Indian Agriculture Industry: An Overview.

4. Department of Agriculture and Cooperation. Ministry of Agriculture, Govt. of India.

5. Pandey MM (2009) Indian Agriculture-An Introduction. Fourth Session of the Technical Committee of APCAEM Chiang Rai, Thailand, pp. 1-39.

6. Arjun KM (2013) Indian Agriculture- Status, Importance and Role in Indian Economy. International Journal of Agriculture and Food Science Technology 4: 343-346.

*Corresponding author: Madhusudhan L, Department of Biotechnology, Joginpally BR Engineering College, JNTU, Telangana State, India, E-mail: madhu.sl@rediffmail.com

Received July 28, 2015; Accepted August 13, 2015; Published August 20, 2015

Citation: Madhusudhan L (2015) Agriculture Role on Indian Economy. Bus Eco J 6: 176. doi:10.4172/2151-6219.1000176

Copyright: (c) 2015 Madhusudhan L. This is an open-access article distributed under the terms of the Creative Commons Attribution License, which permits unrestricted use, distribution, and reproduction in any medium, provided the original author and source are credited. 